TEME, г. XLIII, бр. 4, октобар - децембар 2019, стр. 1045-1061

\begin{tabular}{lr}
\hline \hline Оригинални научни рад & https://doi.org/10.22190/TEME191015062K \\
Примљено: 15. 10. 2019. & UDK 316.774:004.738.5(497.11) \\
Ревидирана верзија: 17. 10. 2019. & \\
Одобрено за штампу: 1. 12. 2019. &
\end{tabular}

\title{
ELECTRIC SCOOTERS \\ - URBAN SECURITY CHALLENGE OR MORAL PANIC ISSUE -
}

\author{
Milica Kolaković-Bojović*, Ana Paraušić
}

Institute of Criminological and Sociological Research, Belgrade, Serbia

kolakius@gmail.com

\begin{abstract}
Triggered by the widespread use of electric scooters in Serbian cities, the authors conducted an empirical research of media discourses in terms of their use and the influence they have on the various aspects of wellbeing in the urban environment. Among other, the authors explore the relation between the use of electric scooters and urban security challenges as seen by newspapers, as well as the lens of the Twitter community in Serbia. Through the identification of the main topics represented in both newspapers and Twitter posts, the ways and tones in which the topics have been addressed, as well as arguments provided to support the publicly expressed attitudes, this paper provides both the quantitative and qualitative analysis of data, attempting to give an answer to whether the use of electric scooters could be considered an urban security challenge or just another issue causing moral panic.
\end{abstract}

Key words: $\quad$ urban security, electric scooters, media discourse, moral panic.

\section{ЕЛЕКТРИЧНИ ТРОТИНЕТИ - ИЗАЗОВ УРБАНЕ БЕЗБЕДНОСТИ ИЛИ ПРЕДМЕТ МОРАЛНЕ ПАНИКЕ}

\footnotetext{
Апстракт

Подстакнути распрострањеном употребом електричних тротинета у Србији, аутори су спровели анализу медијског дискурса у вези са утицајем његове употребе на општу добробит у урбаним срединама. Између осталог, аутори су истражили везу између употребе електричних тротинета и изазова урбане безбедности, посматрано у светлу новинског извештавања, као и ставова корисника Твитера у Србији. Кроз препознавање кључних тема заступљених у оба извора - у новинским чланцима и објавама на Твитеру; доминантних тонова и приступа у адресирању ове теме, као и аргумената изложених у прилог јавно заузетим ставовима - аутори рада дају квантитативну и квалитативну анализу података, тражећи при томе одговор на питање: „Треба ли употребу електричних тротинета посматрати као изазов урбаној безбедности или као само још једну од тема које служе за повод стварања моралне панике?”.

Кључне речи: урбана безбедност, електрични тротинети, медијски дискурс, морална паника.
} 


\section{INTRODUCTION}

For academics and practitioners, the issue of urban mobility and quality of transportation infrastructure is of the utmost significance for the quality of life and citizens' wellbeing, hand in hand with urban security. As a contested concept, urban security comprises diverse security problems (challenges, risks and threats), strategies and actions taken to tackle these problems in order to protect important values, as well as different actors, i.e. providers participating in the achievement and enhancement of security in the urban environment (Paraušić \& Lipovac, 2019, p. 257). Defined in this manner, security not only involves the protection against traditional and serious threats, such as armed conflicts or terrorism, but also concerns the broader framework of providing the adequate quality of life (Paraušić, 2019), including the functioning of urban transportation infrastructure. In the past two years, vehicles with electric engines descended in masse in cities all around the world. The main ideas surrounding the introduction of alternative means of transportation are the reduction of traffic jams and air pollution in the urban environment, and the alternatives include transportation such as electric scooters, segways, hoverboards, etc. ${ }^{1}$

The recent introduction of electric scooters in urban environments has triggered a significant research interest in various social and security aspects of their use. Existing studies have primarily focused on the social impacts of these scooter services (Petersen, 2019; Loizos, 2018) and parking placements (Fang et al., 2018), and acceptance rates (Riggs, 2018; Degele et al., 2018). Additional research has centered on the distribution optimization (Chen et al., 2018), the electrical engineering-focused efforts towards efficient batteries (Pellegrino et al., 2010), the reduction of personal automobile usage (Smith \& Schwieterman, 2018), as well as the spatial and temporal analysis between e-scooters and other AVs (McKenzie, 2019). Moreover, one recent study focused on safety concerns of one e-scooter company (Bird) conducting an analysis of the official Instagram profile (Allem \& Majmundar, 2019).

But as the number of e-scooters rises, they have been received with the moral panic and outburst of the wider public. Moral panics are described as volatile moments characterized by heightened concerns about a group, its conduct or a particular event; hostility against the perpetrators; disproportionality in the depiction of the threat; and a consensual reaction to it (Cohen 2002; Goode \& Ben-Yehuda, 1994). In some American cities, public officials have used safety concerns as a reason to ban the little dockless vehicles (Gutman, 2018), and in other, safety was cited as a main

\footnotetext{
${ }^{1}$ Scooter companies and their promoters argue that they can offer a space-efficient, environmentally friendly, car-reducing way to get around the city. They are cheaper than cabs, require less effort than a bicycle and more convenient than buses.
} 
driver behind the proposal to jail scooter users who exceed a 15 -mph speed limit or ride on the sidewalk (Philipsen, 2019). They are also labelled as a threat to the security of pedestrians, other drivers and urban transportation in general, as well as the cause of significant amount of crashes and injuries (Trivedi et al., 2019; Bresler et al., 2019; Kobayashi et al., 2019). Just how many problems and health concerns they actually cause, and to what degree city officials and other regulators should care, remains a topic of dispute.

Despite the increased interest of the academic community for electric scooters, the percentage of injuries involving alternative vehicles in general is comparatively far from that of other means of transportation (car accidents above all). Moreover, the expected number of injuries or crashes may be likely due to the exponential rise in the number of drivers of escooters, e-bikes, hoverboards and such. Nevertheless, the so-called scooter-skeptics seized on the news as a proof that these "disruptive devices" indeed represent a safety and public health issue. As it is evident, electric scooters in the academic discourse, as well as in the public debate are presented in a two-fold manner: as alternative innovative means of transportation, on the one hand and as an urban security challenge potentially endangering the citizens' mobility in the city, on the other.

Having all the above mentioned in mind, the overall objective of this paper is to explore whether the use of electric scooters could be considered an urban security challenge or just another issue causing moral panic. More specifically, this research strives to uncover the relation between the use of electric scooters and urban security challenges as seen by the mainstream newspapers, as well as the lens of the Twitter community in Serbia. Our primary goal is to identify the main topics represented in both- newspapers and Twitter posts, the ways and tones in which they have been addressed as well as arguments provided to support the publicly expressed attitudes.

Considering this, we aim to answer three basic research questions:

- What were the main discussions on Twitter and news media since the mass introduction of e-scooters in urban transportation?

- What similarities and differences could emerge by contrasting the thematic findings from Twitter and newspapers?

- Does the response of users on Twitter and newspapers mimic that of moral panic? 


\section{METHODOLOGY \\ Research Phases and Sampling}

This research was conducted in the period between June and September 2019, with the dynamic divided into two research phases:

\section{Research phase I: Analysis of the daily newspapers' reporting on the use of electric scooters}

During this stage, we examined the media coverage of the e-scooters in leading agenda-setting newspapers, precisely, their websites from June to September 2019. Eight popular daily newspapers were selected: Novosti ${ }^{2}$, Blic $^{3}$, Politika ${ }^{4}$, Danas ${ }^{5}, \mathrm{Alo}^{6}$, Kurir ${ }^{7}$, Informer ${ }^{8}$ and Srpski telegraf ${ }^{9}$. Considering the wide audience they gather, we found them relevant for framing the public discourse on the main research problem. ${ }^{10}$ The initial search of the daily newspaper portals yielded a total of 248 articles. After reviewing and eliminating duplicates, as well as articles where the electric scooters were mentioned incidentally, or non-motorized scooters were in question, the final sample reached the number of 115 newspaper articles.

Research phase II: Analysis of Twitter posts on the use of electric scooters

In order to get a more complete picture of the discussion about electric scooters on the city streets, the survey also included a Twitter analysis with its dynamics and debates. We analyzed posts made on Twitter in the six weeks' period (July $24^{\text {th }}$ to September $4^{\text {th }}, 2019$ ) that had been previously identified as the pick of media reporting on electric scooters. We focused exclusively on posts written in Serbian in order to get results on attitudes toward electric scooters in Serbian urban communities (mostly in Belgrade). We identified 304 posts that fulfil the above mentioned criteria. ${ }^{11}$ Posts' coding process showed that some of

\footnotetext{
${ }^{2}$ http://www.novosti.rs/ last accessed September 25, 2019

${ }^{3} \mathrm{https}: / /$ www.blic.rs/ last accessed September 25, 2019

${ }^{4} \mathrm{http}: / /$ www.politika.rs/ last accessed September 25, 2019

${ }_{6}^{5} \mathrm{https} / / /$ www.danas.rs/ last accessed September 25, 2019

${ }^{6} \mathrm{https} / / / \mathrm{www}$. alo.rs/ last accessed September 25, 2019

${ }^{7} \mathrm{https} / / / \mathrm{www}$. kurir.rs/ last accessed September 25, 2019

${ }^{8} \mathrm{https}: / /$ informer.rs/ last accessed September 25, 2019

${ }^{9} \mathrm{https} / / /$ www.republika.rs/najnovije-vesti

${ }^{10} \mathrm{https} / / /$ serbia.mom-rsf.org/rs/mediji/print/ last accessed September 24, 2019

${ }^{11}$ In order to avoid the contamination of the sample, we decided to exclude 36 posts written in the middle of the analyzed period that mentioned electrical scooters, but only as a side issue while discussing political topics. Namely, a local Belgrade politician who belongs to the non-ruling party used the electric scooter to show that the reconstruction of the streets in the city center resulted in extremely unpleasant conditions to drive electric scooters in that part of the city. This attracted significant interest of Twitter users and the public in general and triggered intense debate. As a result of that debate, numerous posts were made. Some of them focused on issues
} 
the posts addressed more than one of the identified topics, meaning that we as the final outcome, analyzed 338 Twitter posts.

\section{Methods}

Content analysis was used as the main research method and the unit of analysis was single text/tweet with all visual and content related parts. Each news/tweet item was examined to identify the main topics, the actors involved, the activities they performed, and how they were characterized. Specifically, the analysis focused on the issue and themes that were considered significant since the introduction of e-scooters on the streets of Belgrade, and how this significance was expressed (in positive, negative or neutral terms).

In terms of procedure, after extracting every single news/post from the newspapers' websites and Twitter, using the Google Tool and Twitter Search option, based on the key words (scooter(s), electric scooter(s), trotinette(s), electric trotinette(s)), each news item or a twit we identified was analyzed after finishing the coding process that had been conducted in order to identify the main topic(s) it addressed, the tone of the news/post, the main arguments (if any) it provided to support the attitude publicly expressed.

\section{FINDINGS}

\section{Daily Newspaper Analysis}

The media reported relatively uniformly on electric scooters, with the only exception being Blic, which has almost double the number of articles published (about $22 \%$ of the total number of articles) compared to the average for other newspapers (about 11\%). After the Blic, most articles were published in Kurir (15), then in the Srpski telegraf (14), the same number of articles were published in Politika and Informer (13 each); Danas has published 12 articles, and Novosti and Alo 11 units each.

Table 1. Number of articles published per newspaper

\begin{tabular}{|c|c|c|c|c|c|c|c|c|c|}
\hline Media & Novosti & Blic & Politika & Danas & Alo & Kurir & Informer & S. telegraf & Total \\
\hline $\begin{array}{l}\text { No. } \\
\text { articles }\end{array}$ & 11 & 26 & 13 & 12 & 11 & 15 & 13 & 14 & 115 \\
\hline$\%$ & 9.5 & 22.6 & 11.3 & 10.4 & 9.5 & 13.1 & 11.3 & 12.3 & 100 \\
\hline
\end{tabular}

relevant for our research and were consequently included in the sample. In contrast, 36 aforementioned posts mentioned electrical scooters exclusively as a side issue while discussing topics in the field of politics, pro and contra the ruling party, on the local level. This qualified them for the exclusion from the research sample. 
The media were particularly active when it came to announcing the adoption of a new Law on Road Traffic Safety, which should regulate the e-scooters use and driving (June $20^{\text {th }}$ ), as well as sharpening penal practice for e-scooter drivers in several European capitals (July $1^{\text {st }}$ ). Interestingly, the news on the arrest of dozens of electric scooters drivers under the influence of alcohol and/or narcotics in Denmark (July $9^{\text {th }}$ ) was particularly interesting for the Serbian media, as was the news about famous youtuber, Emily Hartridge's death while driving e-scooter in the UK $\left(\right.$ July $\left.15^{\text {th }}\right)$. Almost all media reported a boy was injured when he was hit by an electric scooter driver (July $31^{\text {st }}$ ), as well as an increased number of road accident victims, where driving this alternative means of transportation was marked as one of safety risks (August $6^{\text {th }}$ ). The Serbian media also paid great attention to the announcement of the city manager, Goran Vesić, who said that the driving of this increasingly popular electric device on the streets of Belgrade must be regulated (August $23^{\text {rd }}$ ). categories $^{12}$ :

Analyzed media articles were distributed in three thematic Thematic category I: Electric scooters as an urban security challenge Thematic category II: Electric scooters as an alternative means of transportation

Thematic category III: Electric scooters as a fashion trend and/or status symbol

Table 2. The main topics of media discourse on electric scooters

\begin{tabular}{|c|c|c|c|c|c|c|c|c|c|c|}
\hline & $\begin{array}{l}\text { Topic/Media } \\
(\%)\end{array}$ & $\begin{array}{l}:= \\
0 \\
0 \\
0 \\
z\end{array}$ & $\stackrel{0}{\mathscr{n}}$ & $\stackrel{\frac{\pi}{3}}{: 0}$ & ڤี & $\stackrel{\circ}{\frac{1}{2}}$ & $\stackrel{\Xi}{\Xi}$ & 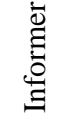 & 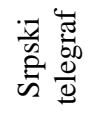 & $\begin{array}{c}\stackrel{ }{\Xi} \\
\stackrel{\Xi}{5}\end{array}$ \\
\hline 1 & $\begin{array}{l}\text { Electric scooters as urban } \\
\text { security challenge }\end{array}$ & 69.2 & 61.5 & 75 & 66.6 & 83.3 & 75 & 64.7 & 81.2 & 70.2 \\
\hline 2 & $\begin{array}{l}\text { Electric scooters as } \\
\text { alternative means of } \\
\text { transportation }\end{array}$ & 30.7 & 28.2 & 18.7 & 22.2 & 16.6 & 20 & 23.5 & 12.5 & 22.5 \\
\hline \multirow{2}{*}{3} & $\begin{array}{l}\text { Electric scooters as a fashion } \\
\text { trend and/or status symbol }\end{array}$ & / & 7.7 & 6.3 & 11.1 & I & l & 11.7 & 6.2 & 6 \\
\hline & Other & I & 2.5 & I & I & I & 5 & I & I & 1.3 \\
\hline
\end{tabular}

The media discourse on the electric scooters is largely shaped by the topic of urban security, which has been mentioned in as many as $70 \%$ of

\footnotetext{
${ }^{12}$ It should be noted that in order to gain meaningful insights, in most cases, we find that more than one topic could be relevant in one article. Therefore, the number in tables referred to the number of topic/subtopic mentions, not the number of articles.
} 
cases. Within the topic of urban security, the media was most concerned with the legal regulation of this means of transportation, as, according to the testimony of the actors, there is a danger for all road users requiring urgent state intervention, and the emergent introduction of electric scooters in the new Law on Road Traffic Safety. Within this sub-topic, the issue of where these vehicles should be driven is particularly relevant. In support of the legal regulation of this area, the media reported on harsher penalties for drivers of e-scooters in European cities, which was motivated, as they say, by numerous road accidents. Somewhat less attention has been paid by the media to the subtopics of the security of other traffic participants, especially pedestrians, where it is often noted that pedestrians may be at risk of injury and even death due to the inappropriate and irresponsible behavior of electric scooter drivers. The sub-theme of e-scooters drivers' safety has been largely addressed through the reporting of accidents in which the lives of the drivers of this alternative vehicle (first of all, the famous UK youtuber, Emily Hartridge) have been lost, and ultimately pose a great danger to the safety of e-scooter owners. Another topic we have identified as relevant is traffic safety in the most general sense, where the media usually point out that electric scooters are the cause of traffic jams and disruptions to the functioning of the city's transportation system, and discourage people from using other eco-friendly means of transportation.

Table 3. Topic 1 - Electric scooters as an urban security challenge

\begin{tabular}{|c|c|c|c|c|c|c|c|c|c|c|}
\hline & Subtopic/media & $\begin{array}{l}\overline{\tilde{w}} \\
0 \\
0 \\
0 \\
z\end{array}$ & $\stackrel{\frac{0}{0}}{\circ}$ & 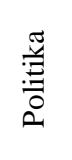 & $\begin{array}{l}\tilde{E} \\
\tilde{\Xi} \\
\tilde{\Xi}\end{array}$ & $\frac{0}{4}$ & $\stackrel{\Xi}{\Xi}$ & 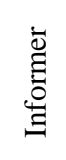 & 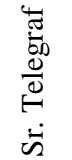 & $\underset{0}{\tilde{0}}$ \\
\hline 1 & $\begin{array}{l}\text { Electric scooters and } \\
\text { legislation }\end{array}$ & 31.8 & 38.1 & 47.6 & 31.8 & 38.8 & 31.8 & 33.3 & 43.4 & 37.3 \\
\hline 2 & $\begin{array}{l}\text { Safety of drivers of } \\
\text { electric scooters }\end{array}$ & 31.6 & 14.3 & 14.3 & 27.3 & 22.2 & 18.2 & 33.3 & 17.4 & 21.1 \\
\hline 3 & $\begin{array}{l}\text { Safety of other traffic } \\
\text { participants, especially } \\
\text { pedestrians }\end{array}$ & 31.6 & 28.6 & 19.1 & 22.7 & 22.2 & 22.7 & 22.2 & 26.1 & 24.9 \\
\hline 4 & Road Traffic Safety & 5.3 & 19.4 & 19.1 & 18.2 & 16.6 & 27.3 & 11.1 & 13.2 & 16.7 \\
\hline
\end{tabular}

To a much lesser extent (22\%), the media pictured electric scooters as an alternative means of transportation that could greatly improve urban transportation infrastructure. In this respect, the sub-themes related to traffic congestion and environmental protection are dominant, as electric scooters have been promoted as eco-friendly vehicles of the future. Somewhat less importance was attached to the sub-topics of technological development, connection with other similar means of transportation (especially bicycles), as well as micromobility. Seen under this second 
major theme, electric scooters as an alternative means of transportation are presented as a leap into the future, which are economical, make life easier for users and save time. In just nine articles, electric scooters are referred to as the impersonation of a new trend that has "plagued" city dwellers, where often its drivers are labeled "yuppies" or "hipsters" and the vehicles themselves are referred as "fashion accessories."

The thematic analysis of media reporting shows that there are no significant deviations in the coverage of individual media. The topic of urban security is the most present in Alo (84\%) and least in Blic (61\%). Another major topic, alternative means of transportation, is mentioned the most in the daily newspapers Novosti and Blic, and least in the Srpski telegraf. Electric scooters as a trend or fashion are recognized by the daily newspapers such as Blic, Politika, Danas, Informer and the Srpski Telegraf.

If we look at the general tone of the reporting, we can conclude that the media in Serbia have created a rather negative image of electric scooters. As many as $72 \%$ of articles have a condemnatory tone, and it can be noted that electric scooters, and especially their drivers, are most often targets of criticism and rarely given the opportunity to speak in their defense. In about $16 \%$ of the reports, journalists took a neutral approach, citing either the technical characteristics of the vehicle, or the legal practice in the field in European countries. Only 12\% of the total number of the content presented the general sense of approval to the e-scooters, emphasizing their cost-effectiveness, positive impact on urban traffic congestion and the environmental benefits.

Table 4. Tone analysis of media discourse on electric scooters

\begin{tabular}{lccc}
\hline Media/Tone (\%) & Negative & Positive & Neutral \\
\hline Novosti & 66.8 & 16.6 & 16.6 \\
Blic & 67.6 & 14.7 & 17.6 \\
Politika & 60 & 0 & 40 \\
Danas & 50 & 25 & 25 \\
Alo & 82 & 0 & 18 \\
Kurir & 93.7 & 6.3 & 0 \\
Informer & 92.3 & 7.7 & 0 \\
Srpski telegraf & 73.3 & 13.3 & 13.3 \\
Total & 71.9 & 11.4 & 16.7 \\
\hline
\end{tabular}

However, the tone of reporting differs significantly when comparing the selected newspapers, which must be taken into account in framing the media discourse on electric scooters in urban environment. Specifically, the percentage of articles in which a negative tone can be identified varies from 50\% in Danas to over $90 \%$ in Alo and Informer. Danas has the largest share of articles that have a positive tone $(25 \%)$, while in Politika and Alo we have not found any articles with positive 
tone. However, the neutral tone is the most obvious in Politika, while Kurir and Informer do not have any neutral coverage. Nevertheless, it is evident that the media in Serbia were extremely reluctant to approach positively this alternative means of transportation, which is in line with the dominant thematic framework, that is, electric scooters as a challenge to urban security.

\section{Twitter Posts Analysis}

Differently from the media reporting analysis, the number of thematic categories was increased to six, as visible from below given list. Thematic category I: Electric scooters' use and impact on health.

Thematic category II: Electric scooters as an alternative means of transportation and/or ecology and financial benefit.

Thematic category III: Electric scooters as an urban security challenge.

Thematic category IV: Electric scooters as a fashion trend and/or status symbol.

Thematic category $V$ : Hate and/or negative attitudes toward electric scooters without providing arguments or reasons in support of this attitude.

Thematic category VI: Affirmative posts about electric scooters without providing arguments or reasons in support of this attitude.

The coding process itself showed that there is a large number of affirmative or negative posts about electrical scooters that do not provide any reasons or arguments to support attitudes of the author. Their authors "just purely expressed love or hate" toward electric scooters. This resulted in establishing two additional categories of posts compared with the analysis of media reporting in order to cluster these posts.

The second important difference in terms of the methodological approach is related to the tone of the posts. All analyzed posts on Twitter were placed in one of two, not three tone categories: positive or negative. Neutral-tone posts were not found, which could be explained by the nature of social networks where people come to express it personal attitudes and opinions, while the purpose of media reports is, before all, to objectively inform citizens on actualities. This results in a certain percentage of neutral tone news, contrary to Twitter posts that are clearly positively or negatively toned.

In addition to the number and tone of posts within the above listed categories, we tried to identify the main issues, discussion subtopics and attitudes for all categories. 
Table 5. The main topics of Twitter debate on electric scooters

\begin{tabular}{|c|c|c|c|c|}
\hline \multirow{2}{*}{\multicolumn{2}{|c|}{ Topic/ Thematic category }} & \multirow{2}{*}{$\begin{array}{c}\text { Number/ } \\
\text { percentage } \\
\text { of posts }\end{array}$} & \multicolumn{2}{|c|}{ Tone of the post } \\
\hline & & & positive & negative \\
\hline \multirow{2}{*}{\multicolumn{2}{|c|}{1 Electric scooters' use and impact on health }} & 16 & 0 & 4 \\
\hline & & $5 \%$ & $0 \%$ & $100 \%$ \\
\hline \multirow{2}{*}{\multicolumn{2}{|c|}{$\begin{array}{l}2 \text { Electric scooters as an alternative means of } \\
\text { transportation and/or ecology and financial benefit }\end{array}$}} & 54 & 28 & 26 \\
\hline & & $16 \%$ & $52 \%$ & $48 \%$ \\
\hline \multirow{2}{*}{\multicolumn{2}{|c|}{3 Electric scooters as an urban security challenge }} & 149 & 6 & 143 \\
\hline & & $44.1 \%$ & $4 \%$ & $96 \%$ \\
\hline \multirow{2}{*}{\multicolumn{2}{|c|}{$\begin{array}{l}4 \text { Electric scooters as a fashion trend and/or status } \\
\text { symbol }\end{array}$}} & 71 & 5 & 66 \\
\hline & & $21 \%$ & $7 \%$ & $93 \%$ \\
\hline & \multirow{2}{*}{$\begin{array}{l}\text { Hate and/or negative attitudes toward electric } \\
\text { scooters without providing arguments or reasons } \\
\text { in support of this attitude. }\end{array}$} & 38 & 0 & 38 \\
\hline & & $11.2 \%$ & $0 \%$ & $100 \%$ \\
\hline \multirow{2}{*}{\multicolumn{2}{|c|}{$\begin{array}{l}6 \text { Affirmative posts about electric scooters without } \\
\text { providing arguments or reasons in support of this } \\
\text { attitude. }\end{array}$}} & 10 & 10 & 0 \\
\hline & & $4 \%$ & $100 \%$ & $0 \%$ \\
\hline \multicolumn{2}{|r|}{ Total number of posts } & $\begin{array}{c}338 \\
(100 \%)\end{array}$ & $\begin{array}{c}49 \\
(15 \%)\end{array}$ & $\begin{array}{c}289 \\
(85 \%)\end{array}$ \\
\hline
\end{tabular}

The coding process showed that the most of Twitter users, almost half of them, who had addressed the issue of electrical scooters did it referring to the topic of urban security $(44.1 \%)$. In terms of the tone of posts, it is quite alarming that $96 \%$ of Twitter users perceived an influence that electric scooters have on urban security as negative, since only $4 \%$ of them do not see the negative impact of electric scooters on the security of scooter drivers and other participants in traffic. ${ }^{13}$

In order to further explore the attitudes of Twitter users who consider the use of electric scooters as urban security challenge, we identify the main subtopics they addressed in their posts. In this regard, five main subtopics were recognized:

Subtopic I: Where to drive-normative uncertainty;

Subtopic II: Threat to other traffic participants

Subtopic III: Threat to other traffic participants;

Subtopic IV: Threat to drivers of scooters

Subtopic V: Threat to both- drivers of scooters other traffic participants

${ }^{13}$ A bit surprisingly, considering the very nature of an alternative transportation means, only $16 \%$ of Twitter users posted about this. More Twitter users, $21 \%$ of them, see electric scooters as a matter of fashion trend and/or status symbol. $11.2 \%$ of those who posted about electric scooters expressed merely negative attitudes regarding this vehicle without providing any reason in support of their claim or addressing any of the above mentioned topics. A very symbolic number of Twitter users (less than $10 \%$ in total) posted about electric scooters and their impact on health $(0.5 \%)$ 
Table 6. Electric scooters as an urban security challenge (total numbers)

\begin{tabular}{llrcr}
\hline No. Subtopic & Number of & \multicolumn{2}{c}{ The tone of post } \\
\cline { 3 - 5 } & & posts & positive & negative \\
\hline 1 & Where to drive-normative uncertainty & 37 & 0 & 37 \\
2 & Electric scooter can cause a fire & 7 & 0 & 7 \\
3 & Threat to other traffic participants & 39 & 0 & 39 \\
4 & Threat to drivers of scooters & 29 & 6 & 23 \\
5 & Threat to both drivers of scooters and & 37 & 0 & 37 \\
& other traffic participants & & & \\
& Total number of posts & 149 & 6 & 143 \\
\hline
\end{tabular}

It is interesting to mention that three out of five categories were almost equally in the focus of Twitter users (Subtopics I, III and V). Subtopic IV was just a bit less in focus, while Subtopic II attracted minor attention of the Serbian Twitter community. Predominantly, the use of electric scooters was addressed in a negative tone (96\%), while only $4 \%$ of the posts are not of the prior idea that the use of electric scooters is an urban security challenge.

Table 7. Electric scooters as an urban security challenge (percentages)

\begin{tabular}{llccc}
\hline No. & \multicolumn{1}{c}{ Subtopic } & $\begin{array}{c}\text { Percentage } \\
\text { of posts }\end{array}$ & \multicolumn{2}{c}{$\begin{array}{c}\text { The tone of post } \\
\text { positive }\end{array}$} \\
& negative \\
\hline 1 & Where to drive - normative uncertainty & $24.8 \%$ & 0 & 37 \\
2 & Electric scooter can cause a fire & $4.7 \%$ & 0 & 7 \\
3 & Threat to other traffic participants & $26.2 \%$ & 0 & 39 \\
4 & Threat to drivers of scooters & $19.5 \%$ & 6 & 23 \\
5 & Threat to both- drivers of scooters other & $24.8 \%$ & 0 & 37 \\
& traffic participants & & & \\
\hline & Total number of posts & $(149$ & 6 & 143 \\
& & & $(4 \%)$ & $(96 \%)$ \\
\hline
\end{tabular}

Subtopic I: Where to drive-normative uncertainty- The total of 37 participants $(24.8 \%)$ addressed the issue of normative uncertainty, but also the lack of awareness issue in terms of where electric scooters should be driven (on the streets/roads or along pedestrian paths). Namely, there is a significant portion of posts that clearly indicates:

a. weaknesses of normative framework which deal with the safety of road traffic;

b. a lack of legal certainty in terms of legal framework applicable on electric scooters and their participation in road traffic;

c. a low level of awareness of citizens regarding the rules and procedures applicable on electric scooters, their drivers and the interaction with other participants in traffic. 
Subtopic II: Electric scooter can cause a fire - The analysis showed that 7 posts $(4.7 \%)$ addressed the risk of use of electric scooters as potential cause of fire when plugged in for charging. All of the post in this subcategory referred to the same accident where an electric scooter in Germany exploded when being charged and caused a fire in the whole building.

The group consisted of three subtopics (III, IV and V) addressed security risks named in Twitter posts referring to the risks of the use of electric scooters for drivers of scooters, other participants in traffic or both of them. This group of subtopics was raised in 105 Twitter posts $(70.5 \%)$ which is a clear sign that electric scooters are generally perceived as an urban security challenge in terms of personal safety.

Within this group of topics, Subtopic III: Threat to other traffic participants - is represented in 39 posts (26.2\%); Subtopic IV: Threat to drivers of scooters - is raised in 29 posts (19.5\%) while Subtopic V: Threat to both- drivers of scooters other traffic participants - is underlined in 37 posts $(24.8 \%)$.

In order to assess whether this attitude is associated with personal or indirect experience in terms of accidents or other incidents caused and/or with participation of electric scooters, we analyzed arguments given in support to publicly expressed concerns. Only 4 of 149 posts addressed the accidents in which the authors took part or witnessed to them. The rest of the posts are based on the authors' attitudes unsupported by experience and/or based on information about accidents from domestic or international media.

\section{DISCUSSION OF THE RESEARCH FINDINGS}

\section{Electric Scooters and Urban Security Challenges}

Despite the broadening of the thematic scope for the three topics in the Twitter analysis, there is an evident overlap between the emerging themes of newspaper articles and Twitter posts. In both cases, the majority of analyzed units $(70.2 \%$ of newspaper units and $44 \%$ of Twitter posts) framed electric scooters as an urban security challenge.

When comparing the subtopics of urban security challenges, we found that it is possible to compare newspapers and Twitter debates in relation to: 1) normative uncertainty and regulation electric scooters; 2) safety of the drivers of electric scooters; 3) safety of other traffic participants; 4) safety of both electric scooter drivers and other participants in traffic. These topics consist almost $100 \%$ of both- newspaper units and posts on Twitter. 
Table 8. Comparing the newspapers and Twitter in relation to the theme of urban security

\begin{tabular}{lcc}
\hline $\begin{array}{l}\text { Subtopic/Media } \\
\%\end{array}$ & Newspapers & Twitter \\
\hline Legislative/normative framework & 37.3 & 24.8 \\
Safety of the drivers & 21.1 & 19.5 \\
Safety of the other traffic participants & 24.9 & 26.2 \\
& & \\
Safety of both electric scooter drivers and other & 16.7 & 24.8 \\
participants in traffic & & \\
\hline
\end{tabular}

Divided in two thematic categories, the data shows that $37.3 \%$ of newspaper units addressed the issue of normative uncertainty in terms of "where to drive issue", and so did $24.8 \%$ of Twitter posts. In addition to the difference in the percentage of posts/news addressing this issue, the approach is different in terms of flagging the issue of citizens' awareness of the existing normative framework which rules the use electric scooters. More precisely, while some Twitter users flagged the existence of such a normative framework emphasizing the lack of citizens' awareness in this regard, there is no track record in the newspapers on the same topic. This is of great importance, having in mind the main purpose and role of newspapers as a traditional media is to inform citizens and/or to raise their awareness of important issues, not to contribute to moral panic.

The second group of subtopics referring to the use of electric scooters as a safety risk for drivers of scooters, other participants in traffic or both of them consists of $62.7 \%$ of news units and $70.4 \%$ of Twitter posts.

Not surprisingly, the tone analysis of newspaper articles and Twitter posts exhibited strong compliance. Although the neutral tone could not be recognized on Twitter as a tool to express personal views, negative attitude toward electric scooters on the streets of the cities is dominant in both cases (around $70 \%$ in newspapers, and up to $85 \%$ on Twitter). This means that the introduction of electric scooters in urban environment was met with a backlash on all levels, from citizens, city officials, media, and the public in general. The media discourse framed the drivers and owners of this vehicle in a distinctively hostile manner, labeling them as an imminent danger to pedestrians and urban traffic.

Table 9. Comparing the tone of the newspaper articles and Twitter posts

\begin{tabular}{lcc}
\hline$\%$ & Positive & Negative \\
\hline Newspapers & 11.4 & 71.9 \\
Twitter & 15 & 85 \\
\hline
\end{tabular}




\section{E-scooters and moral panic}

The case of e-scooter related issues in Belgrade could be characterized as a case of moral panic to the extent that it generated a consensual, volatile and disproportionately hostile reaction to a particular group, however difficult it may be to identify membership of that group (Goode \& Ben-Yehuda, 1994). Indeed, the media narrative examined here contained key features of moral panic: a) concern about a conduct or practice; b) hostility against the perpetrators; c) consensus in the reaction; d) disproportionality in the depiction of the threat; e) volatility of the episode (the media reporting and a period of intense anxiety emerging quickly and then dissipating).

Regarding the first feature of moral panic, the concern about the electric scooters in urban transport is evident since the media and the Twitter users, in the majority of the cases, framed this vehicle as an urban security challenge, either with the view of regulations and penalties (going as far as calling it "a new anarchy"), or in terms of it being a threat to pedestrians, traffic, as well as the drivers themselves. Owners and drivers of electric scooters are presented in overtly negative tones, labeled as "silent killers", "hipsters", "arrogant yuppies", "junkies", "sectarians", etc. Almost all the media reported on dozens of e-scooters drivers' arrests abroad due to being under the influence of alcohol and drugs, accentuating and disapproving of their inappropriate and reckless behavior. Citizens manifested great consensus in their reaction to electric scooters in the streets, expressing the fear for their safety and resentment toward this alternative means of transportation. Public officials also reacted to the introduction of electric scooters in urban transportation, calling for urgent law reform and regulations regarding this vehicle. Media panic is clearly manifested in the constant and repeated reporting on how dangerous driving of electric scooters could be, "causing numerous injuries, even deaths", without referencing to official data for Serbia. Moreover, only one accident causing an injury happened in Belgrade and was reported on in the newspapers. Similarly, as mentioned earlier, only 4 of 149 posts addressed the accidents in which the authors took part or witnessed to them. The rest of the posts were based on the authors' attitudes unsupported by experience and/or based on information about accidents from domestic or international media.

There were also instances of using the term "war" between e-scooter drivers and pedestrians, as well as between city officials and drivers. Media reporting on electric scooters was marked by short period of intense publicity, followed by a significant decrease in coverage. Electric scooters on the Belgrade and European streets were the subject of media reporting mostly during July and August ${ }^{14}$, with as many as $74 \%$ of the analyzed material.

\footnotetext{
${ }^{14}$ Reporting pick, also chosen as analyzed period for Twitter analysis
} 


\section{CONCLUDING REMARKS}

The results of the research indicate a significant thematic overlap between newspaper reporting and discussion on Twitter. Namely, the security challenges of the use of electric scooters as an alternative means of transportation have been recognized as a priority issue by both Twitter users and journalists. In addition to that, the tone of the public discourse on electric scooters in an urban environment is markedly negative, meaning that users and drivers of electric scooters have been the target of constant criticism when reporting and debating on Twitter.

Considering the extreme attention they have attracted, the unduly hostile attitude towards the users, the consensus in the public reaction, the disproportionality in reporting/describing the supposed safety risks compared to the actual number of accidents/incidents, the short but intense period of reporting and discussions on Twitter, we can conclude that the media discourse on electric scooters on city streets has all the main features of moral panic.

As the number of electric scooters on the streets continues to increase, and considering that over time their use will lose the character of a new phenomenon, we believe that conducting a follow-up survey after 12-18 months could yield significant results. Furthermore, it is expected that after this period, official data on potential incidents or accidents caused or involving electric scooters might be available, thereby allowing for the media discourse to be observed with regard to this novelty in the context of objective data.

\section{REFERENCES}

Allem, J. P., \& Majmundar, A. (2019). Are electric scooters promoted on social media with safety in mind? A case study on Bird's Instagram. Preventive medicine reports, 13, 62-63.

Bresler, A. Y., Hanba, C., Svider, P., Carron, M.A., Hsueh, W.D. \& Paskhover, B. (2019). Craniofacial injuries related to motorized scooter use: a rising epidemic. American journal of otolaryngology, 40(5), 662-666.

Chen, Y. W., Cheng, C. Y., Li, S. F., \& Yu, C. H. (2018). Location optimization for multiple types of charging stations for electric scooters. Applied Soft Computing, 67, 519-528.

Cohen, S. (2002). Folk Devils and Moral Panics: The Creation of the Mods and Rockers. (3rd edn). London: Routledge.

Degele, J. et al. (2018). Identifying e-scooter sharing customer segments using clustering. In: Proceedings of the 2018 IEEE International Conference on Engineering, Technology and Innovation (ICE/ITMC). IEEE, pp. 1-8.

Fang, K., Agrawal, A., Steele, J., Hunter, J., Hooper, A. (2018). Where do riders park dockless, shared electric scooters? Findings from San Jose, California. (Tech. rep). San Jose: Minnesota Transportation Institute.

Garland, D. (2008). On the concept of moral panic. Crime, Media, Culture: An International Journal, 4(1), 9-30. doi:10.1177/1741659007087270 
Goode, E. \& Ben-Yehuda, N. (1994/2009). Moral panics: The so-cial construction of deviance (2nd edn.). Chichester, U.K; Malden, MA: Wiley-Blackwell.

Gutman, D. (2018, September 30) Seattle embraced dockless bike shares, but bans scooter ones. How come? The Seattle Times Retrieved from: https://www.seattletimes. com/seattle-news/transportation/seattle-embraced-dockless-bike-shares-but-bansscooter-ones-how-come/

Kobayashi, L. M., Williams, E., Brown, C. V., Emigh, B. J., Bansal, V., Badiee, J., ... $\&$ Doucet, J. (2019). The e-merging e-pidemic of e-scooters. Trauma Surgery \& Acute Care Open, 4(1), e000337.

Loizos, C. (2018, September 22). A lime scooter rider died in Washington, D.C., marking the second fatality this month. TechCrunch Retrieved from: https://techcrunch.com/2018/09/21/a-lime-scooter-rider-died-this-morning-inwashington-d-c-marking-the-second-fatality-this-month/

McKenzie, G. (2019). Spatiotemporal comparative analysis of scooter-share and bikeshare usage patterns in Washington, DC. Journal of Transport Geography, 78, $19-28$.

Paraušić, A. (2019). Bezbednost u gradovima van granica nacionalnog i lokalnog Politike urbane bezbednosti evropskih organizacija [Security in the cities beyond national and local: Urban security policies of European organizations]. Revija za kriminologiju i krivično pravo [Journal of Criminology and Criminal Law], 57(2), 99-111.

Paraušić, A., Lipovac, M. (2019) Karakteristike pretnji urbanoj bezbednosti [Characteristics of the urban security threats]. Politička revija [Political Review], 2/2019, 255-277.

Pellegrino, G., Armando, E., Guglielmi, P. (2010). An integral battery charger with power factor correction for electric scooter. IEEE transactions on power electronics, 25,(3), 751-759.

Petersen, A. B. (2019). Scoot over smart devices: The invisible costs of rental scooters. Surveillance \& Society 17 (1), 191-197.

Philipsen, C. (2019, January 29) Scooter regulations: A tempest in the teapot. Community Architect Daily Retrieved from: https://communityarchitectdaily. blogspot.com/2019/01/scooter-regulations-tempest-in-teapot.html

Riggs, W. (Ed.). (2018). Disruptive Transport: Driverless Cars, Transport Innovation and the Sustainable City of Tomorrow. London: Routledge.

Smith, C. S., Schwieterman, J. P. (2018). E-scooter scenarios: Evaluating the potential mobility benefits of shared dockless scooters in Chicago (Tech. rep.). Chicago: Chaddick Institute for Metropolitan Development at DePaul University.

Trivedi, T. K., Liu, C., Antonio, A. L. M., Wheaton, N., Kreger, V., Yap, A., ... \& Elmore, J. G. (2019). Injuries associated with standing electric scooter use. JAMA network open, 2(1), e187381-e187381. 


\title{
ЕЛЕКТРИЧНИ ТРОТИНЕТИ - ИЗАЗОВ УРБАНЕ БЕЗБЕДНОСТИ ИЛИ ПРЕДМЕТ МОРАЛНЕ ПАНИКЕ
}

\author{
Милица Колаковић-Бојовић, Ана Параушић \\ Институт за криминолошка и социолошка истраживања, Београд, Србија
}

\section{Резиме}

Подстакнути распрострањеном употребом електричних тротинета у Србији, аутори су спровели анализу медијског дискурса у вези са утицајем њихове употребе на општу добробит у урбаним срединама. Између осталог, аутори су истражили везу између употребе електричних тротинета и изазова урбане безбедности, посматрано у светлу новинског извештавања, као и ставова корисника Твитера у Србији. Кроз препознавање кључних тема заступљених у оба извора - новинским чланцима и објавама на Твитеру; доминантних тонова и приступа у адресирању ове теме, као и аргумената изложених у прилог јавно заузетим ставовима - аутори овог рада дају квантитативну и квалитативну анализу података, трагајући при томе за одговором на питање: „Треба ли употребу електричних тротинета посматрати као изазов урбаној безбедности или као само још једну од тема које служе за повод стварања моралне панике?”.

Истраживачка стратегија подразумевала је рад у две фазе: Прво смо анализирали текстове у популарним дневним новинама, а затим смо спровели анализу твитова који су у вези са електричним тротинетима на улицама градова. Резултати спроведеног истраживања упућују на значајно тематско преклапање између новинског извештавања и дискусије на Твитеру. Наиме, као доминантни тематски оквир препознали смо електричне тротинете као изазов урбане безбедности, те се може закључити да су корисници Твитера, као и аутори новинских текстова, пре свега скретали пажњу на опасности које са собом носи коришћење овог алтернативног превозног средства на градским улицама. Осим тога, тон јавног дискурса о електричним тротинетима у урбаном окружењу изразито је негативан, што значи да су корисници и возачи електричних тротинета били мета непрестаних критика приликом извештавања и дебате на Твитеру.

Имајући у виду изразиту пажњу коју су изазвали нескривено непријатељски став према корисницима, консензус у реакцији јавности, непропорционалност у приказу опасности, кратак, али интензиван, период извештавања и дискусије на Твитеру, можемо закључити да медијски дискурс о електричним тротинетима на градским улицама има све главне одлике моралне панике. 